\title{
The Industry Life Cycle in an Economic Downturn: Lessons from Firm's Behavior in Spain, 2007-2012
}

\author{
Caridad Maylín-Aguilar ${ }^{1}$ (D) . Ángeles Montoro-Sánchez ${ }^{2}$
}

Received: 7 July 2020 / Accepted: 1 September 2020 / Published online: 14 September 2020

(c) Springer Nature Switzerland AG 2020

\begin{abstract}
This paper presents the main results of the application of the Industry Life Cycle model in the study of stagnant and declining businesses. The main purpose was to prove its validity to assess the competitive environment, in a context of economic turmoil as the one of the 2007-2008 economic downturn. The comparison of macro and micro data at a national level, with managerial declaration of behavior of a sample of firms with declining demands, revealed that there was a mismatch on the interpretation of the environment and strategic conduct and this impacted in the overall performance of the industry. Our findings stress the need for a dialogue between researchers and practitioners, in order to provide better advice and directions to adapt to unfavorable circumstances, because of the long-lasting effects of downturn and the current COVID-19 crisis.
\end{abstract}

Keywords Industry life cycle · Declining demand · Firms' objectives and behavior

JEL Classification L16

\section{Introduction}

The Industry Lifecycle (ILC) provides a model to incorporate the dynamism of the environment into the competitive analysis of the context a company operates (Miles et al. 1993). Building in the initial phases of the product life cycle (Levitt 1960), the ILC model combines the analysis of the sector's structure (Porter 1980) with the study of the behavior and results of companies (Teece 2007).

Caridad Maylín-Aguilar

caridad.maylin@ufv.es

Ángeles Montoro-Sánchez

mamontor@ucm.es

1 Facultad de Ciencias Jurídicas y Empresariales, Universidad Francisco de Vitoria, Ctra. Pozuelo-Majadahonda, Km. 1,800, 28223 Pozuelo de Alarcón, Madrid, Spain

2 Complutense Institute for International Studies, Universidad Complutense, Campus de Somosaguas, Ctra de Húmera 96E, 28223 Pozuelo de Alarcón, Madrid, Spain 
Although some fundamental criticisms to the evolutionary, and somehow fatalistic, pattern of the ILC (Levitt 1960, p. 45), the stylized shape of industry evolution gives an overall picture of the potential path of industries and a foresight of the national economy (Dieli 2020), a motive of internationalization (CuervoCazurra, Narula and Un 2015; Vernon 1966) and a framework to compare within industries (Karniochina et al. 2013).

To strategy scholars, analyzing the feasibility of models as a guide, or at least a recommendation, for public policy makers and practitioners is important given a general landscape of stagnation in the advanced economies (International Monetary Fund, IMF 2017) and the forecasted impact of the current COVID-19 crisis (Fernandes 2020), in economies largely populated by mature industries. These deep, large jolts in finance or in demand, can accelerate the transition from stability to decline (McGahan 2004) trapping important domestic industries in a nightmare of reducing demand, therefore jobs, and finally profits.

In this work we review the adequacy of ILC as theoretical framework and model to analyzing and comparing firm's actual behavior and results with theory's prescriptions, focusing in a large and traditional industrial sector and considering the effects of 2008 recession in Southern European economies. The economic recession left companies without the resources required given the need to change or cease operating (Bloom 2014) in a "post-growth", scenario (persistent stagnation, stalled growth, high unemployment and inequality, Jackson 2019). Spanish financial crisis worries the general population during the worst of the peak but also throughout its duration (Araújo-Vila et al. 2020).

Within that context, we regard specifically the situation of Food and Beverages (F\&B) industry, as one of the most important industries in the world economy. We focus in an industry that supplies basic, sustenance goods, to distinguish cyclic trends from conjuncture jolts. Recent reports on the COVID-19 consequences show an overall stability (Reportlinker 2020), confirming its consideration of countercyclical (Oster 1999). The industry processes raw materials to create food products and then package and distribute them through various distribution channels to both individual customers and establishments. The global F\&B market was estimated to be worth over $\$ 5,650$ billion in 2017 and segments include alcoholic and non-alcoholic beverages, pet food, tobacco, grain products, meat, poultry and seafood, fruit and vegetable canning, pickling, and drying, frozen food and dairy. Globally, the bipolar structure of the sector consists of large multinationals on the one hand and a large number of domestic small and medium-sized (SMEs) companies on the other. The industry has witnessed a continuous pattern of growth with two different speeds, around $3 \%$ in major Western economies, while the emerging and new industrialized economies grow twice that rate (Reportlinker 2018). In Spain, the F\&B industry is the largest in terms of turnover and employment with some 28,000 companies, annual production amounting to 119 billion euros, and more than 500,000 people employed in the sector (Spanish national institute of statistics, INE 2017). The industry's exports have shown positive growth since the mid-1990s as part of an ongoing, long-term effort, and not just as a reaction to the recent effects of the recession (Simon-Elorz et al. 2015). That said, both the percentage of income dedicated to 
consumption and the volume of food consumed fell in the period from 2008 to 2018 .

In the empirical part of the paper we share the learnings from a study of behavior and results of Spanish F\&B firms during the last decade. Using a mixed methods approach, we follow the ILC model and its empirical research, and particularly, the model for mature and declining industries developed by Harrigan and Porter (1983). The research question simply asked "Can the ILC theoretical model help policy makers and managers identifying and reacting to the signals of the environment?". In order to answer that, first objective of the study was to confirm if the drop down of sales and profits observed in the period was part of industry's evolution or a consequence of the 2007-2008 shock and lack of public and private financing, the abandonment of active innovation and productivity policies (Tong et al. 2016). A parsimonious application of the ILC thresholds (Dieli 2020; Hall 1980; Harrigan 1980; Karniouchina et al. 2013) to public data on consumption in a period previous and during the shock (2000-2010) revealed the existence of nine declining segments in a seemingly stable and counter-cyclical industry.

Second objective refers to the second part of the question, reaction. Drawing from the prescriptions of the model for declining business (Harrigan 1980; Harrigan and Porter 1983; Porter 1980), the answer conveys analysis and comparison of the actual strategic conduct of the firm with the one proposed by the model. In order to do so, a primary-source survey was addressed to top management of firms active in any of the nine declining business. The empirical comparison unveils differences between the model prescribed conduct and the enacted one, leaving an open question of the consequences of this imbalance between environment, firms' competitive position and conduct.

The analysis and discussion with experts of possible reasons and solutions for this imbalance lead to the conclusions of the study, that reinforces us about the validity of studying the environment through academic models as the ILC, however the strategic prescriptions have to accommodate to the long-lasting persistence of stagnant and declining demands and the behavior of companies that challenge the deterministic view of the model renewing the value proposition (Henderson 1995), adding services (Cusumano et al. 2015) or introducing disruptive, innovative business models (Christensen and Raynor 2003). This renewal and the shared discussion of findings with industry experts and practitioners will place us in a better position to be able to deal with the future and create new trade opportunities for firms and their products.

Our paper contributes to the review of the economic scenario from a company's viewpoint. Foreseeing the characteristics of the industry and forecasting the possible evolution of demand can add clarity to a scenario which is, to put it mildly, uncertain. Events as the global economic shock of 2007 and the COVID-19 pandemic, destabilize the institutional environment and noticeably modify the formal and informal rules of the game for those operating in the market and change the evolution dynamics of the industry (McGahan 2004). Therefore, a shared understanding of decreasing demands due to a temporary jolt, or due to a persistent reduction, is a relevant first step. Growth stagnation is a complex situation which is hard to manage as the lack of munificence in their environments reduces the options open to companies (Porter 1980). On the second hand, reviewing the options and opening 
opportunity windows (as internationalization, Cuervo-Cazurra et al. 2015), alliances with competitors, buyers and suppliers, customers' cocreation, servitization of products (Argyres et al. 2015; Christensen and Raynor 2003; Cusumano et al. 2015) and collaborative networking are some of the recipes that can change the bitter taste of decline, when "a fractionally lower price gets the business" (Levitt 1980).

The article is organized as follows. The first part is the literature review, with a summary of the ILC model postulates and revisions, and after there is a summary of the main traits of the framework and strategic model for declining business, as introduced by Harrigan (1980). The literature review ends with the proposition of the empirical validation of framework and model, that is covered in the third section, Empirical study. Discussion of results and conclusions are the final part of the paper.

\section{Literature Review and Theoretical Framework}

\subsection{The Industry Life Cycle Model}

From the viewpoint of industrial organization (IO), an industry is defined on the basis of its demography and evolution, and the strategic behavior of companies reflects the adjustment of their resources and capabilities to meet the demands of the market. The SCP continuum (Structure, Conduct, Performance) and the concept of fit reveals the importance of a sound and depth analysis of the context. Among the models suggested in the literature to analyze sectors, the industry life cycle (ILC) model is one of the most accepted as it combines the analysis of the sector's structure (Porter 1980) with the study of the behavior and results of companies (Teece 2007) competing in a certain industry (Miles et al. 1993).

The key features of the industry's attractiveness, growth and the average return in the sector are associated with the stages of the life cycle (Karniouchina et al. 2013). Changes in these two factors influence the strategic conduct of companies, affecting rivalry and the uncertainty of decision-making (Harrigan and Porter 1983). The maturity stage is characterized by falling prices, due either to intense competition among a decreasing number of companies (Klepper 1996) or to the decline of the market (Cusumano et al. 2015). The transition from maturity to decline is a result of a state of "saturation": the product turns into a commodity, demand is almost reduced to replacement and competition becomes more hostile, with price wars breaking out due to an increase in the price elasticity of demand and falling customer loyalty. The stages of the model explain the evolution and generate proposals for behavior that help executives adapting and adjusting the strategic conduct to the environment (Porter 1991).

From its original formulation, the existence of an evolutionary pattern for a product from its birth to its eventual maturity and death (Levitt 1960), has been countered by the reality of businesses and industries that contradict this fatalist determinism and establish the uniqueness of each market (Henderson 1995). Maturity in homeland market is a key driver of internationalization (Vernon 1966) as firms' can extract additional advantage of slack resources and knowledge, trading standardized, globalized merchandises (Levitt 1983). Even more, while the exposition to 

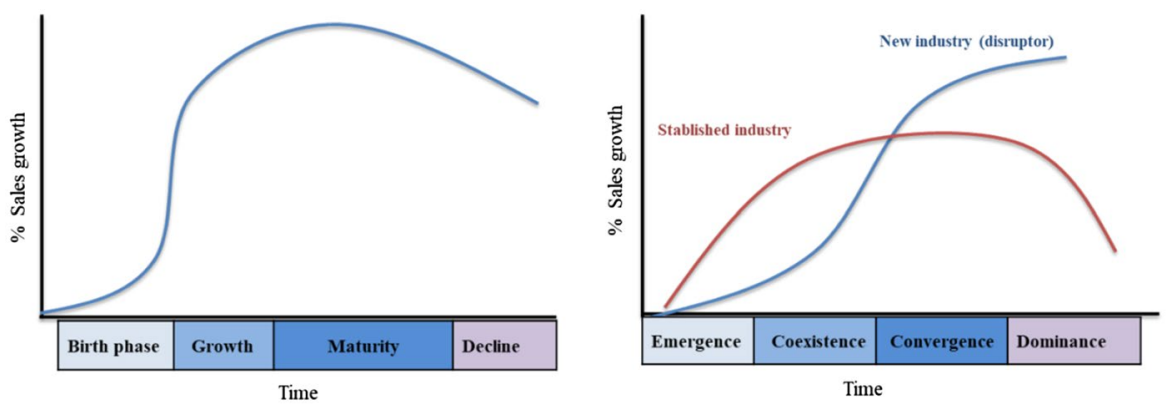

Fig. 1 Industry life cycle traditional and alternative trajectories and phases. Source: McGahan (2004, p. 93)

international trade gives additional knowledge to improve and refine existing products (O'Sullivan 2020), increasing their appealing to the homeland or international market, the weight of country exports in the global trade and its link to national growth can be related with the phase of ILC (Audretsch et al. 2017; Dieli 2020). ${ }^{1}$

Among other effects, the initial model is refined by the consideration of the impact of technology (Klepper 1997) and, at a later stage, of the effect of disruptive innovation (Christensen and Raynor 2003). McGahan (2004) summarizes that there is not a single shape, as there are different trajectories, due to the industry itself (a stablished, or a new one) and also because the type of change firm is facing (radical, creative, intermediating or progressive). An established industry on progressive change can maintain its volume if competing firms develop incremental changes to keep customers' interested in their solution; on the other hand, if there is a radical or intermediating change (in the key assets or relations), customers will be offered the existing and a new solution and the trajectory of the industry will change depending on their choice, after a period of coexistence, when both solutions have volume enough to flourish, and convergence, where a dominant design replaces the existing one (Argyres et al. 2015; Audretsch and Feldman 1996). Therefore, she suggests a change towards a two trajectories cycle, depending on the solution (Fig. 1)

Even though decline appears as the end of the cycle, with its associated loss of profitability and company closures, the empirical evidence shows that certain industries go through a fifth (upturn) and sixth (renewal or decline) stage after maturity. Porter (1980) points out that the creation and acquisition of new patents initiates a cycle of renewal. As well as technological innovation, the upturn can be due to the ability to "reinvent" the product's use (Levitt 1960). Henderson (1995) differentiates innovative maturity (when companies successfully promote these new uses) or growth maturity (when thanks to the continued acquisition of new users, sales grow at the rate of the population). In this continuum of intermediate stages between maturity and decline, incremental innovations of the product and its use sustain the industry, without growth but with absolute levels of turnover and profitability that

\footnotetext{
${ }^{1}$ We gratefully acknowledge JBCY anonymous reviewer by highlighting us this fruitful area of research.
} 


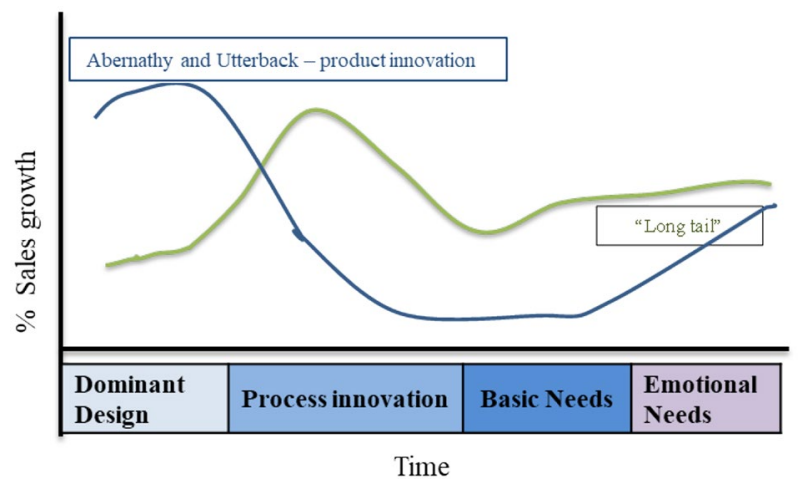

Fig. 2 Product and process innovation in the Industry life cycle. Source: Fujimoto (2014, p. 9)

justify its continuance. Fujimoto (2014) studies the evolution of the automotive industry to reflect that, once the dominant design solution is accepted and the orders depend on replacement, as penetration of the industry product is high, firms focus in process innovation, giving an incremental source of growth due to scale economies and productivity gains (Lean production) that increased the customer base. After that replacement rate can accelerate due to active listening to customer needs (safety, ecological cars). The industry growth is low or almost inexistent, but the volume is large enough to maintain employment and profitability. This period is classified as long tail (Klepper 1996), dematurity or petrified demand (Harrigan 1980) (Fig. 2). If the industry is unable to complete this incremental renewal it stops being attractive for its customers and demand falls, leading to the start of the decline stage (McGahan 2004). Firm's survival in the mature stage is related to market power (Porter 1980) and enhanced productivity (Esteve-Perez et al. 2018).

\subsection{Theoretical Framework: Harrigan and Porter's Model for Declining Businesses}

(In) the decline stage... more firms exit and the industry concentrates around the few remaining competitors. Growth vanishes, resulting in intensified rivalry and shakeout ... Efforts to meaningfully differentiate often fail and the surviving firms look to scale economies, international markets, and other efficiency or process-oriented advantages to compete. This concentration continues the trend toward lower intra-industry heterogeneity in the decline stage, implying a further increase in the importance of industry effects (Karniouchina et al. 2013, p. 1012).

In the evolutionary pattern of ILC, decline is not a one-off situation, a punctual discontinuity that can be overcome (Harrigan 1980). The decline phase is an endgame where former strategies must be thoroughly reviewed (Harrigan and Porter 1983). We should add that there has been little research into the strategy options for this stage (Parker and Helms 1992) and that the alternative in the ILC (harvest 
Table 1 The Harrigan and Porter model for end-game strategies

The company has competitive strengths The company lacks competitive relative to others strengths relative to others

\begin{tabular}{lll}
$\begin{array}{l}\text { Favorable industry struc- } \\
\text { ture for decline }\end{array}$ & Stay: Leadership or Niche & Exit: Harvest or Quick Divestment \\
$\begin{array}{l}\text { Unfavorable industry } \\
\text { structure for decline }\end{array}$ & Stay: Niche or Exit: Harvest & Exit: Quick Divestment \\
\hline
\end{tabular}

Source: Harrigan and Porter (1983 p. 117)

and exit) is neither unique nor easy to implement (McGahan 2004). There is considerable evidence that companies and executives suffer with an exit (Elfenbein and Knott 2015). Taking a Darwinist approach can lead to a loss of heterogeneity in the industry as it favors companies with the greatest resources-mainly financial ones (Bamiatzi et al. 2016).

Harrigan (1980, 1988) systematization of her findings and previous research (Hammermesh and Silk 1979; Hall 1980) led on the construction of a model of strategic behavior that poses decision on managers' cognition of the environment and their own relative forces to competitors (Harrigan 1980, p. 2). Companies can choose to stay or exit (fight or flee, Harrigan 1988 p. 11). The strategic alternatives of Harrigan (1980, p. 44) were reformulated as pure competitive strategies (Porter 1980 , p. 321), giving rise to the widely known model (Harrigan and Porter 1983, p. 117) depicted in Table 1 . This model is firmly based on the contingent approach to the context characteristic of the new industrial economy, and its substantial contribution has been the denial of determinism in behavior (harvest or exit) in this final stage of the cycle. Concurrent and subsequent studies (Hall 1980; Hammermesh and Silk 1979; Thiètart and Vivas 1983) added empirical evidence. In this model, the recommended behavior ("stay" or "exit") depends on whether the environment is diagnosed as favorable or unfavorable as regards staying, and can involve pure strategies of differentiation or cost aimed at leadership or focusing on a niche in order to stay, an immediate exit (divest now) or an exit after harvesting (milking). Harrigan (1988 p. 32) refined this model, adding an intermediate stage, both in demand structure and company's relative position.

Drawing from ILC model and indicators, and the decline's framework (assessment of the environment and competitive position of the company), we posit that it is possible with public and firm's information, to understand what is the position of each company in the competitive context, and to evaluate the challenges of the strategic choice, towards Stay, or towards Exit. However, as main empirical contribution focus in particular aspects of competitive strategies (pure or mixed, Parker and Helms 1992), recommend tactics (servitization, Calori and Ardisson 1988; Cusumano et al. 2015), suggest diversification (McGahan 2004; internationalization, Cuervo-Cazurra et al. 2015), foster innovation and entrepreneurial orientation to turn around the firm (Martin and Eisenhardt 2004; Stopford and Baden-Fuller 1994), the full sequence of context evaluation, firm's strategic conduct and results has been scarcely studied since its formulation. Therefore, it is necessary to validate 
framework and model as a tool to answer how managers identify the signals of the environment when the market ceases to grow, or falls down, and how is the strategic reaction that fits the best with this context, and firm's objectives in terms of sales and profit.

\section{Empirical Validation of Framework and Model}

\subsection{Context: The Food and Beverage Industry in Spain}

The key features of the F\&B industry at a European level show its importance for the economy of the EU and its member states. It is a relevant one, as it accounts for $14 \%$ of industrial companies (29\% in France) and $15 \%$ of the employment $(21 \%$ in Spain). Secondly, this industry has also shown stability within Southern Europe, a region suffering relatively severe consequences of the 2007 economic shock, as Italy and Spain reported the largest figures in terms of public debt, unemployment and fall in GDP (IMF 2017). This stability confirms the general understanding of a countercyclical industry (Oster 1999). In Spain, the population of active companies in 2019 show a slight recovery $(30,730$ when there were 28,792 in 2013 , a very similar pattern of the one of the total economy, 3,363,197 in 2019 while there were $3,146,579$ in 2013). However, and as forecasted by IMF 2017 prospective, recuperation is weak as the total number of companies is still below the one in $2008(-1.7 \%$ total economy, $-1.8 \%$ SIC 20) and many of them (56\% in total Spain, 23\% SIC 20) are self-employment units (INE, census on active companies, DIRCE 2019).

The comparison with Spanish industry as a whole show that it is an important sector, as it is the largest industrial sector (in terms of total sales, for $23.3 \%$ of manufacturing activity and is the largest industrial employer (504,900 people, $20.2 \%$ of total industry, with an increasing trend of 1.1\% from 2010, Spanish Ministry of Agriculture, fishery and food, MAPA 2018, p. 214) and its contribution to GDP stands at 2.7\% (MAPA 2017). Its turnover is significantly higher than that of the second ranked sector, motor vehicles (66,370 million euros in 2015, INE). In addition to be large, the industry is diversified. Comparing with the last available official results from the 2017 financial year for the various sectors of SIC code 20 (INE Structural statistics on industrial companies, EEE) shows different levels of turnover and profitability. Empirical research on technological intensity classifies it as a low-intensity industry, in keeping with the classification suggested by the Organization for Economic Cooperation and Development, OECD and its limited innovation. This low investment in technology and R\&D impacts in the attractiveness in terms of potential profitability, measured by the ratio of added value to turnover (Fischer and Schornberg 2007), as it is lower than that for industry as a whole (17.4\% SIC code 20, 21.4\% total SIC manufacturing, 2017 figures). The VAT ratio of the 3 and 4 digits SIC segments, as detailed in Table 2, reflects, in one hand, the internal dynamics of each subsector in terms of transformation of the agricultural product but also, as we will discuss when examining the industry, the impact of the consumption patterns and the concentration and asymmetry among producers and the bargaining power of customers. 


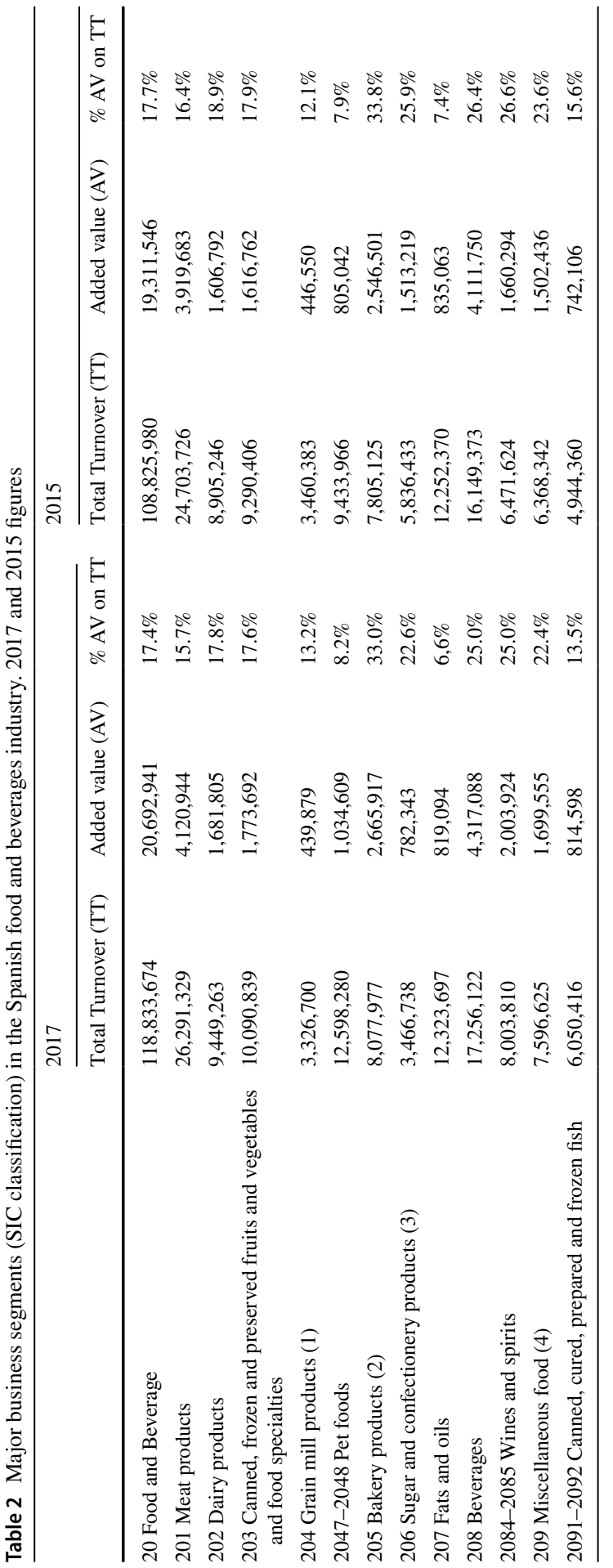

商品

我我

这云遂

缕

要 $=\frac{\pi}{2}$

压

过

पे

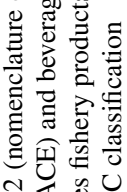

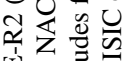

幽 o

$z . \Xi \frac{0}{0}$

画을

3.

을 릉

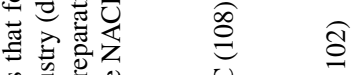

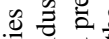

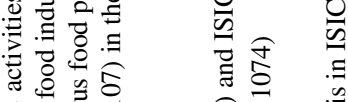

내의

पे क्ष

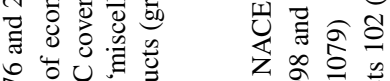

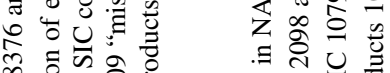

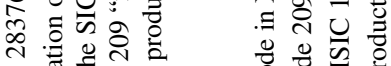

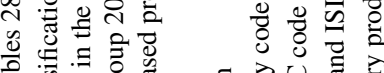

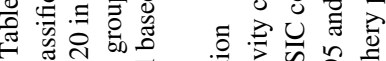

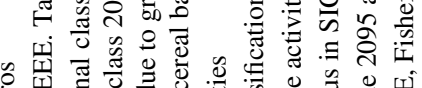
的言名.

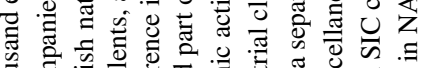

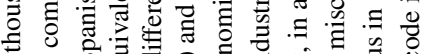

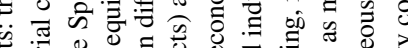

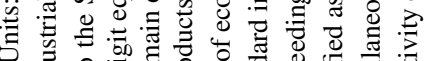
S

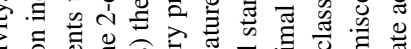
政

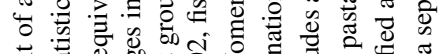

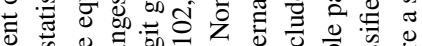

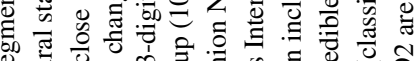

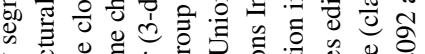
전

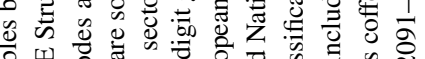
데

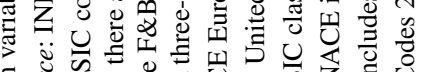
$\overrightarrow{0}$

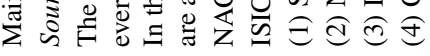


Although typically classified as a local-scale industry, Spanish companies export an increasingly significant part of their production $(28 \%$ of total sales take place abroad, MAPA 2017).

\subsection{Identification of the ILC Phases of Maturity and Decline: Consumption Patterns}

Once the industry is described, now we study industry internal dynamics using the ILC model, in order to answer the first part of our question, how can policy makers and managers identify the future evolution of their businesses. We now set out the process followed to determine the position of the various businesses in the industry and if there is any that can be classified as in the maturity or decline stage. Industry evolution thresholds can be placed in the demand side, from industry outcome (Harrigan 1980) or from consumption (Hammermesh and Silk 1979). In the supply side, changes among phases consider industry shipments (Audretsch et al. 2017), the number and evolution of firms (shakeouts, Klepper 1996) or the number of innovations (McGahan and Silverman 2001). In this research we have used, and suggest for subsequent studies, the consumption indicator. Household spending, dietary habits and perceptions of environment are widely studied by the national statistical services (Campelo et al. 2020). We use specifically the MAPA panel, which since 1987 has compiled the consumption of Spanish families both inside and outside the home. The period chosen for the analysis of trends and subsequent forecasting is 10 years, between 2000 and 2010, to diagnose trends before the 2007 shock.

At a methodological level, the use of such a panel overcomes some obstacles when diagnosing and forecasting. The first is the need to use a robust indicator which avoids inference errors to the greatest extent possible. In this case the panel and its use provide the different perspective offered by the global vision of consumption compared to consumption per capita. Food consumption grew by $11.5 \%$ in Spain in absolute volume terms (2000-2010). However, during this period the Spanish population increased by $11.9 \%$ (INE), but the forecast for the Spanish population for 2014-2020 includes a fall of two million people due to immigrants returning and Spanish citizens emigrating. Taking into account the impact of the change in demographic forecasts on the evolution of this sector (Harrigan 1980, p. 156, unexpected fall in the sales of baby food due to reduced fertility), we reviewed the consumption per capita figures, following Hammermesh and Silk (1979, p. 162 "the fact that consumption per person-of coffee-has fallen even more rapidly suggests that this trend - downwards - will continue"). The consumption per capita indicator helps chart the trend beyond the global figure for sales, consumption or production. Also, using the volume indicator overcomes the potential bias of price volatility, huge in mature and declining businesses (Levitt 1980).

Secondly, it helps to have consistent data. Having a panel with almost 30 years of observations helps overcome the absence of out-of-home consumption data since 2011 and the census change in 2014, which unfortunately prevent us from making year-on-year analyses during that period. However, the robustness of the previous trends confirms the initial inference as stable or showing a slight reduction, 
classifying the industry as a whole as mature, with slight year by year changes (2018 domestic consumption per capita was of $629.96 \mathrm{~kg} / \mathrm{l}$ compared to of $633.36 \mathrm{~kg} / \mathrm{l}$, and it was $656.7 \mathrm{~kg} / \mathrm{l}$ in 2015) (Food Consumption Report 2018; MAPA).

As food and beverages consumption is detailed (SIC 4 digit codes and more), it allows for the identification of significant variations. In this way we create robust indicators of trends and oscillations in demand (Dess and Beard 1984; Miles et al. 1993), that helps us to identify growing segments (prepared food, pet foods), stagnant (meat, fish, fruit and vegetables) and declining, following the threshold of a relevant decrease (no lower than $10 \%$ over a period no shorter than 10 years, Hammermesh and Silk 1979; Harrigan 1980, 1988). The growing turbulence in consumption markets leads to ever shorter cycle changes, so having a longer period softens volatility (Karniouchina et al. 2013). In this way we identify, using figures on total and per capita consumption for the main F\&B businesses detailed in Table 3 and associated by the authors with their SIC code, nine groups and classes in a situation of decline between the years 2000 and 2010 (oil, milk, sugar, rice, coffee, fruit juices, bread, spirits and wine). The effect of the environment has been controlled for by observing the evolution by time period and comparing this with total gross domestic product, GDP (Hall 1980).

\subsection{Validation of the Decline Framework and Model: Variables, Measures and Sample}

Once the business segment is located in the decline phase, giving answer to part of the first question, the following step in the model standardized by Harrigan and Porter (1983) is the analysis of the environment as either favorable or unfavorable for the continuance of the company. Two dimensions determine this classification, decline in demand and structure of the industry. The factors that quality the decline in demand are: (1) The rate at which consumption is falling and the yearly oscillation rate at which this is taking place; (2) The causes and predictability; (3) Its recognition and (4) The existence of profitable and lasting demand pockets within the industry in decline. These constitute a total of 10 indicators. Regarding the structure of the industry, this is defined by its features as hospitable or hostile which are determined by examining: (1) The characteristics of the industry's product; (2) The bargaining power (of customer and suppliers); (3) Competitive rivalry and (4) The existence of exit barriers. These constitute a total of 16 indicators. Previous research of decline is extremely helpful when it comes to suggesting the variables that identify these features (Audretsch and Feldman 1996; Covin and Slevin 1989; Dess and Beard 1984; Hall 1980; Hammermesh and Silk 1979; Harrigan 1980; Harrigan and Porter 1983; Karniouchina et al. 2013; McGahan and Silverman, 2001; Miles et al. 1993; Parker and Helms 1992; Thiètart and Vivas 1983) and their measures, coming from secondary sources (MAPA, INE, Nielsen, Kantar and Spanish industrial federation, FIAB). We checked that these variables and measures were consistent with EU food segments indexes (Fischer and Schornberg 2007).

After configuring the first dimension of the framework with variables and measures from secondary sources, the next step was to create a sample of 


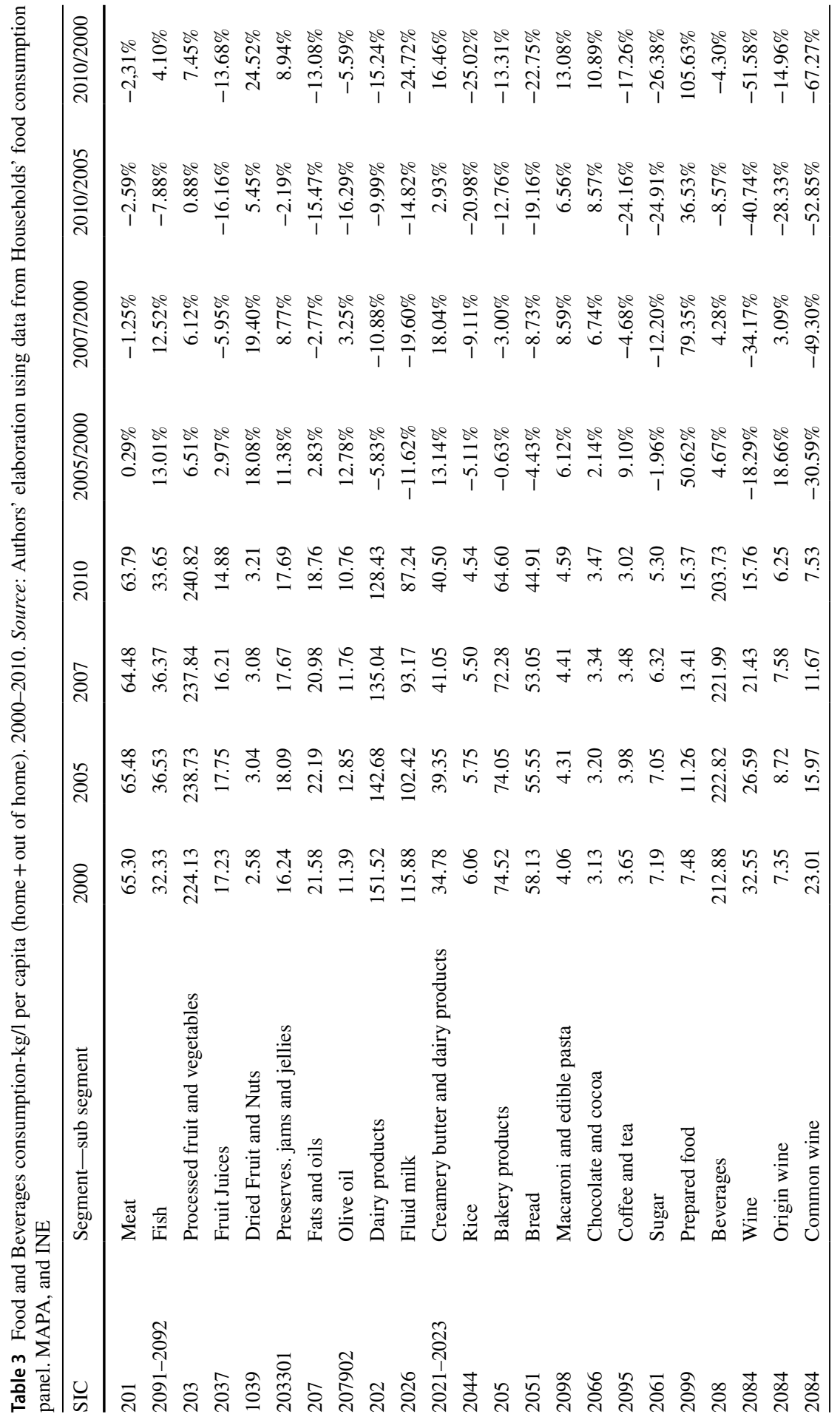




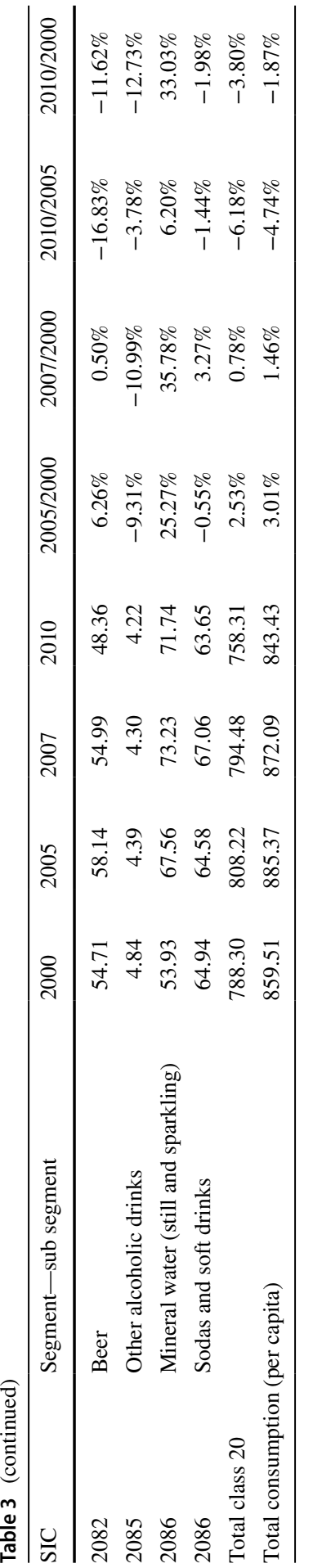


competing companies to classify according to their position and observe their strategic conduct. The nine food groups SIC classification result in a population of 2368 competing companies identified in the Spanish balance database (OrbisBureau van Dijk). Then, a questionnaire was mailed to the general manager or owner. The final sample of 265 firms represents $11.7 \%$ of the companies contacted, similar to other research with this census; however, respondents give short detail on their performance and financial indicators, therefore we come to archival data, but the sample for the relation conduct-results is reduced to 229 firms with their balance sheet available through Orbis-Bureau van Dijk database. The features that determine the competitive position dimension of the company are grouped into two large blocks: (1) The competitive strength of the company and (2) Having (or not having) intangible assets, tangible assets and capabilities that sustain a competitive advantage and include diversification and flexibility competences and skills. The variables that describe it are created from the company's answers to the survey, as questions have been constructed in accordance with the relevant literature, resulting in 18 indicators of firm's competitive position, in terms of market power, assets, intangible, physical and financial resources, capabilities and skills (Barney 1991; Caves and Porter 1977; Grant 1991; Harrigan 1980,1988; Martin and Eisenhardt 2004; McGahan and Silverman 2001; Porter 1980; Teece 2007; Thiètart and Vivas 1983).

The previous variables and their combinations will give us answer to the first question, if the ILC model is a useful tool to understand and analyze the business environment. The second one is about the model and the adequacy of the strategic prescriptions The variable conduct (strategic choice) recommended for the firm's competitive position and the evaluation of the environment are "fight or flee", stay or exit (Harrigan 1988, p. 11). In accordance with the model, competitive strategies (Harrigan and Porter 1983) to be followed to stay are differentiation, costs, market power and niche, and to exit, harvest or exit. To identify the strategy deployed by the company we can consider archival measures (as the ratio of advertising on sales, Thiètart and Vivas 1983). However, this approach in decline is problematic, as there is confusion among focusing in a niche or harvesting (McGahan 2004). Therefore, we use taxonomic grouping of items that express the activities and reflect the strategic alternative of the firm (Narver and Slater 1990), through additive scales. Although additive scale is common practice, we faced the difficulty of adapting some of the declaration to rarely described activities, as milking the declining business. With regards to the strategy option to stay using as competitive strategy pure differentiation and costs, the scales update Dess and Davis (1984) with Acquaah and Yasai-Ardekani (2008) innovative differentiation, and differentiation by service (Cusumano et al. 2015). Cost efficiency is expressed as improvements in processes and productivity (Madhavaram and Hunt 2008). Stay due to market power is described through items that include actions that identify this (acquisitions, price wars) in the previous literature and also in the case of niche (Burpitt and Fowler 2007; Leitner and Güldenberg 2010). Exit option covers actions related to divestiture (immediate exit), while harvest (milking) include employment cuts, reduction of investments and market scope. With these proposed items we can distinguish between general efficiency and productivity actions, necessary in decline (Parker and Helms 1992), and harvest actions, and we cover the two 
possible implementations of the strategy, as a route to a final exit or a prelude to the turnaround in the competitive position.

\subsection{Results: How Can Managers Identify Environment Signals and Firm Position}

Table 4 summarizes the mean and the standard deviation of the variables that measure the favorability of demand and the hospitality of industry. Demand falls during the period $2000-2010$ at rate of $-8.4 \%$; standard deviation value $\left(\sigma^{2} 6.8 \%\right)$ shows the variation among SIC codes, with SIC 2084 (wines) decreasing at $-19.2 \%$ while oils and fats show a positive pace $(+2.1 \%)$. Demand decrease can be forecasted if there are legislative impositions (SIC 202, dairy with 18 events in 10 years) but this sight does not affect in firm's exits, as the number of firms remains stable. The existence and size of niches of profitable demand identifies coffee and herbal teas as a segment with positive perspectives, showing the initial success of coffee capsules (a change in the product architecture and business model that reverses the secular decrease of the segment, Argyres et al. 2015) Considering industry and following the classical discussion from Porter's five forces we control for competitive intensity, bargaining power, differentiation traits and height of exit barriers. Concentration (measured by the Herfindahl index of share on market) is low (mean 0.866) although one segment, sugar and candy, is very concentrated (5.45 index). However, asymmetry is high (Gini index on size and sales, 0.714) even though is not surprising in an industry where the only 59 big companies (more than 500 employees) account for $50.3 \%$ of the total turnover of industry (MAPA 2018).

Once the variables have been designed and the information gathered, we check whether, in accordance with the theory, it is possible to combine them in such a way that they provide a diagnosis of whether the structure of decline is hospitable or hostile. The method of classifying observations through cluster analysis is appropriate for sorting the subjects, in this case business units or companies, into homogeneous groups of which we are not aware in advance but that are instead suggested by the data themselves (Dess and Davis 1984; Harrigan 1985). The procedure we have applied consists of a cluster analysis using the average distance cluster agglomerate method (k-mean). Figure 3 represents the solution for the demand dimension, with two groups, the first representing an unfavorable demand scenario (high reduction rate, volatility) and the second representing a favorable decline in demand. Similarly, the industry dimension generates a two-group solution, reflecting businesses that have a structure that is hospitable (national brands, higher R\&D expenses, more concentration but less asymmetry) or hostile (higher competitive intensity, bargaining power of customers) (Fig. 4).

Following the theoretical framework, the structure of decline is favorable when favorable demand coincides with a hospitable industry. With the information on the two dimensions we can create a second combination of these using cluster grouping. The two-group solution has a significant difference according to the ANOVA test. The breakdown of the solution by SIC group and class (see Table 5) shows the relationship predicted by Harrigan and Porter (1983) between unfavorable attributes of demand (dairy products, wine) and a hostile industry 


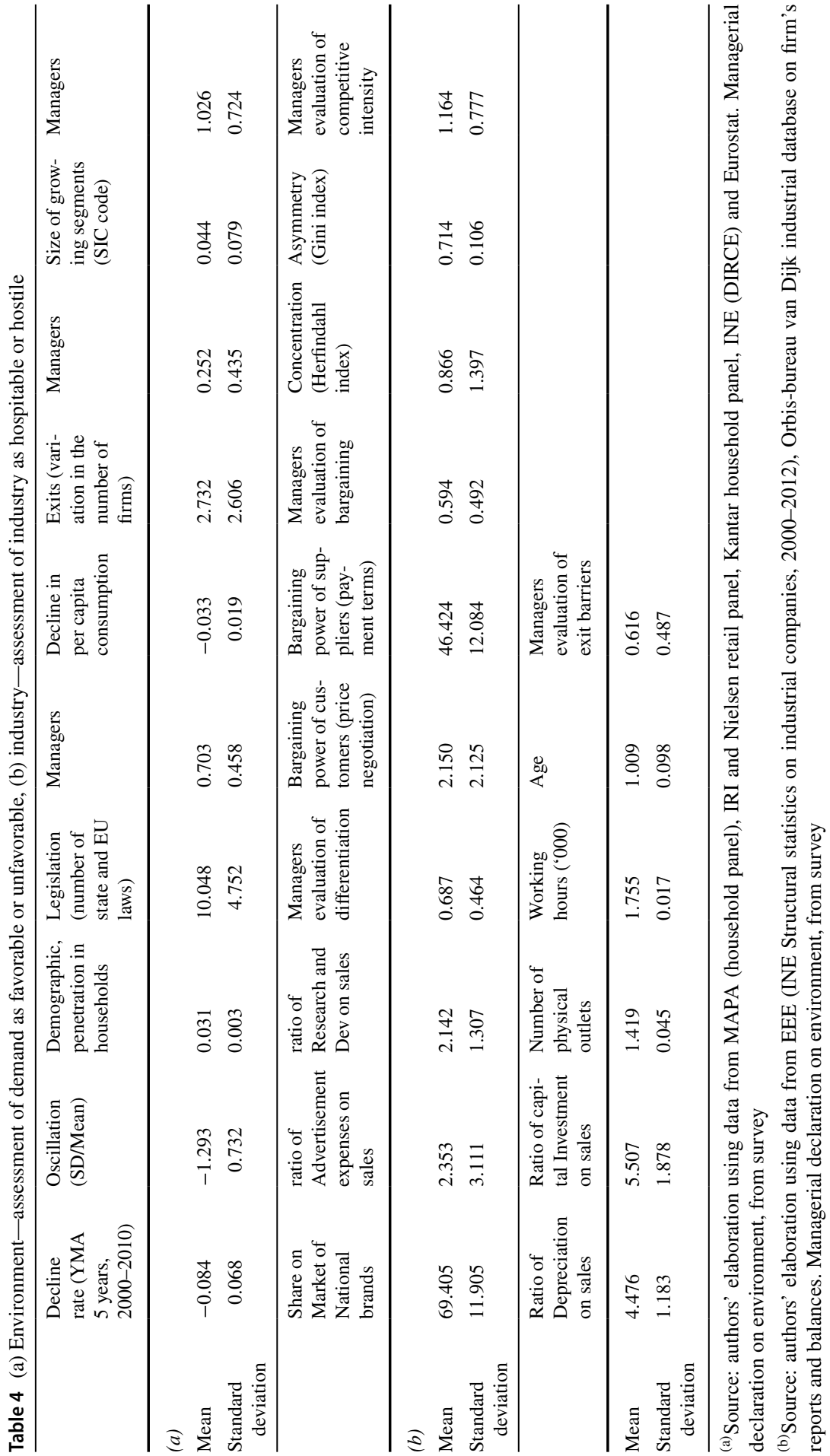




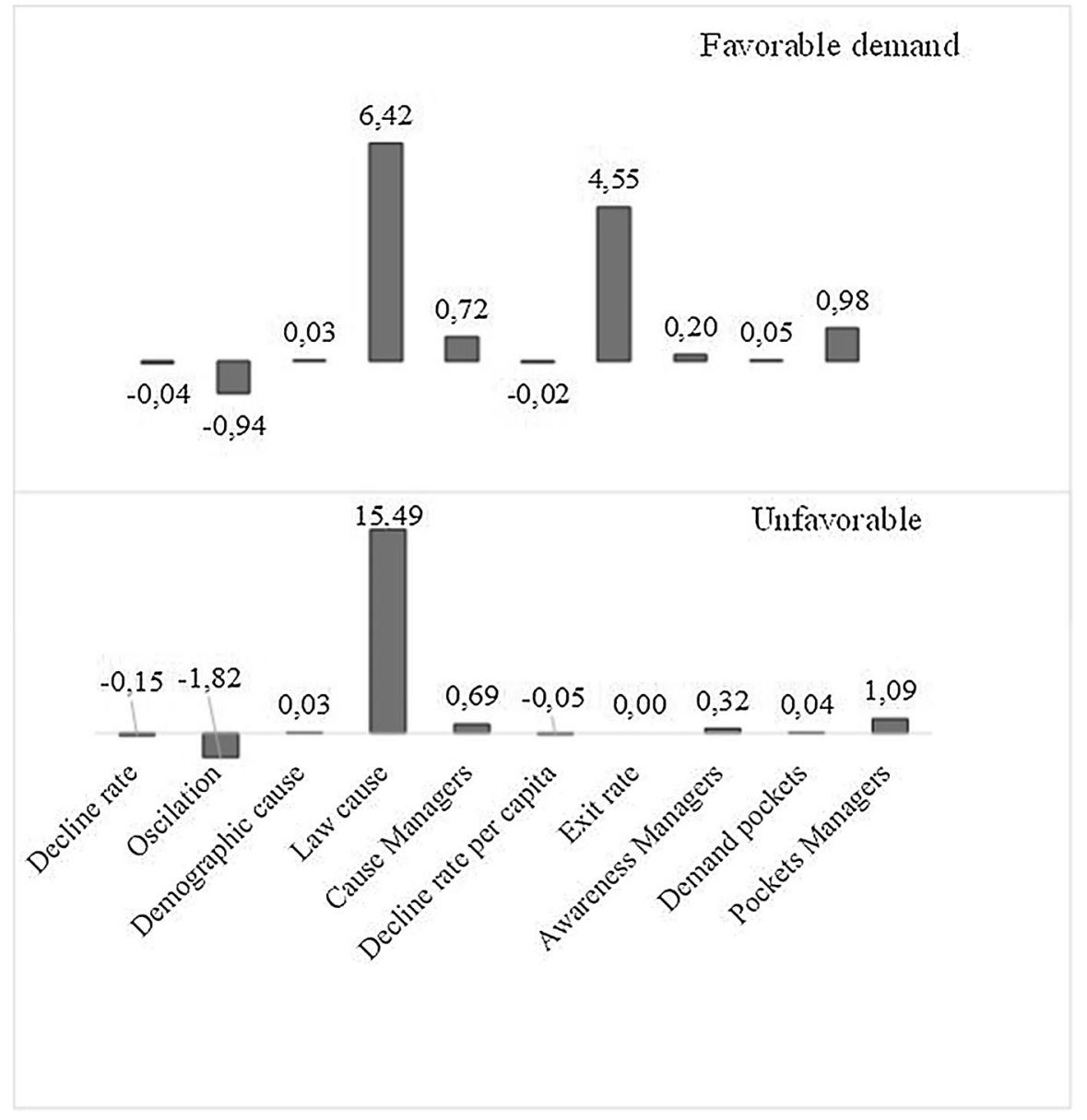

Fig. 3 Assessment of the environment. Favorability of Decline Dimension. Source: authors' elaboration using data from secondary sources and firms' survey

structure (oil, rice and juice), leading to an unfavorable decline structure. Companies competing in these businesses will have, as suggested by the behavior model for decline, greater difficulty in exploiting opportunities, as the environment is less conducive to their continuity. The classification of the businesses included in each of these groups was then discussed with former practitioners and industry experts, who agree that it is, overall, appropriate. Therefore, this first part of the framework and the model is validated and we proceed to the second entrance of the framework, company's competitive position.

Figure 5 plots the variables that describe company's competitive position once been combined using cluster analysis. The three relative positions of strong, weak and intermediate competitive position are in line with that proposed by Harrigan's (1988) expanded framework, added to the original framework. Former practitioners and industry expert identify in that group manufactures of private 


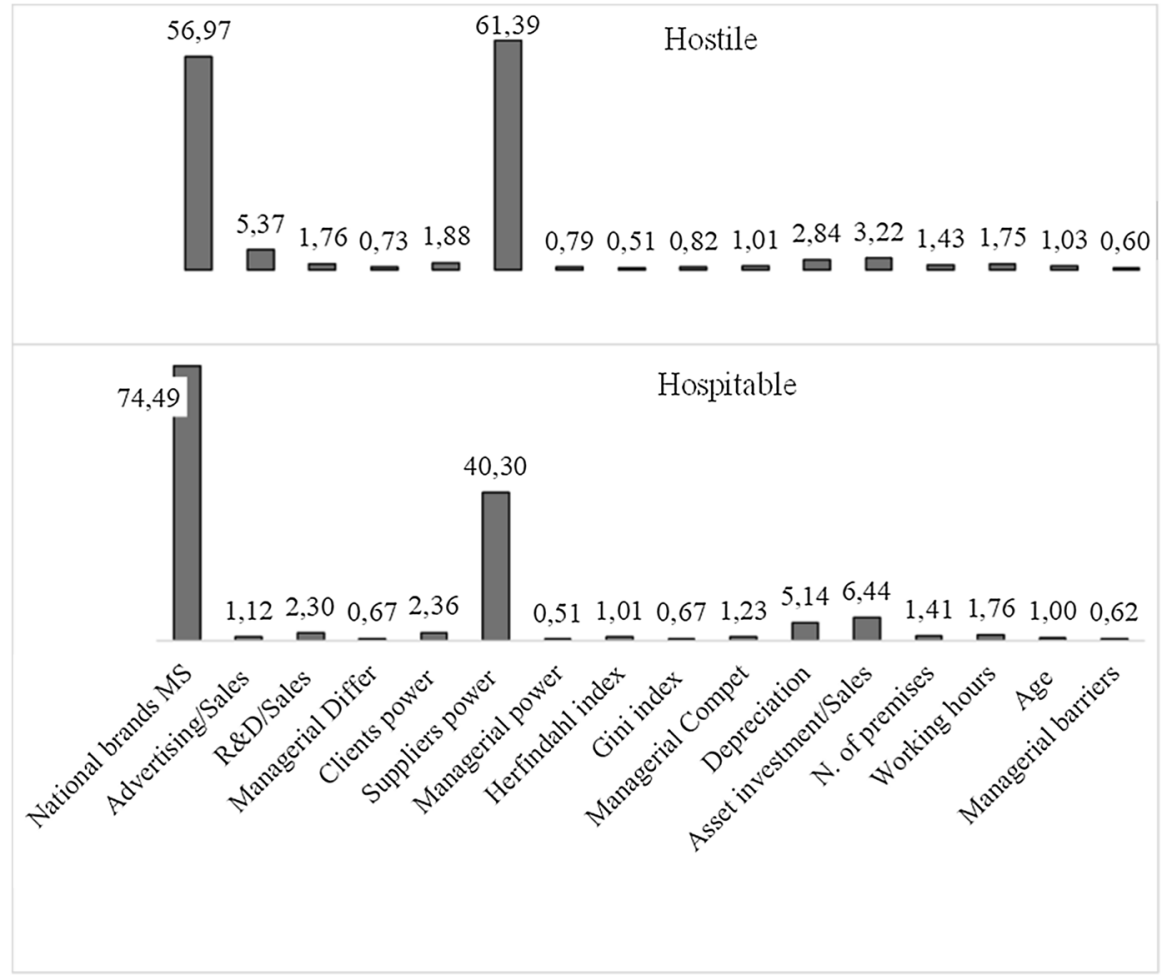

Fig. 4 Assessment of the environment. Hospitality of Industry Dimension. Source: authors' elaboration using data from secondary sources and firms' survey

Table 5 Final assessment of the decline structure by SIC group and class. Source: Authors' elaboration using survey and secondary data

\begin{tabular}{llll}
\hline SIC group and class & Demand dimension & Industry dimension & Decline structure \\
\hline 207 fats and oils & Favorable & Hostile & Unfavorable \\
202 dairy & Unfavorable & Hostile & Unfavorable \\
2037 fruit juice & Favorable & Hostile & Unfavorable \\
204 grain mills and rice & Favorable & Hostile & Unfavorable \\
205 bakery products & Favorable & Hospitable & Favorable \\
2061 sugar & Favorable & Hospitable & Favorable \\
2095 coffee and tea & Favorable & Hospitable & Favorable \\
2085 liquors & Favorable & Hospitable & Favorable \\
2084 wine & Unfavorable & Hospitable & Unfavorable \\
\hline
\end{tabular}

label, or bonded factory for other brands, that are extremely efficient but appear in the lowest rank of investment in advertising or innovation. These companies act as disruptors (Christensen and Raynor 2003) as their activity increases the commoditization of industry`s product, but they are a major force in household 

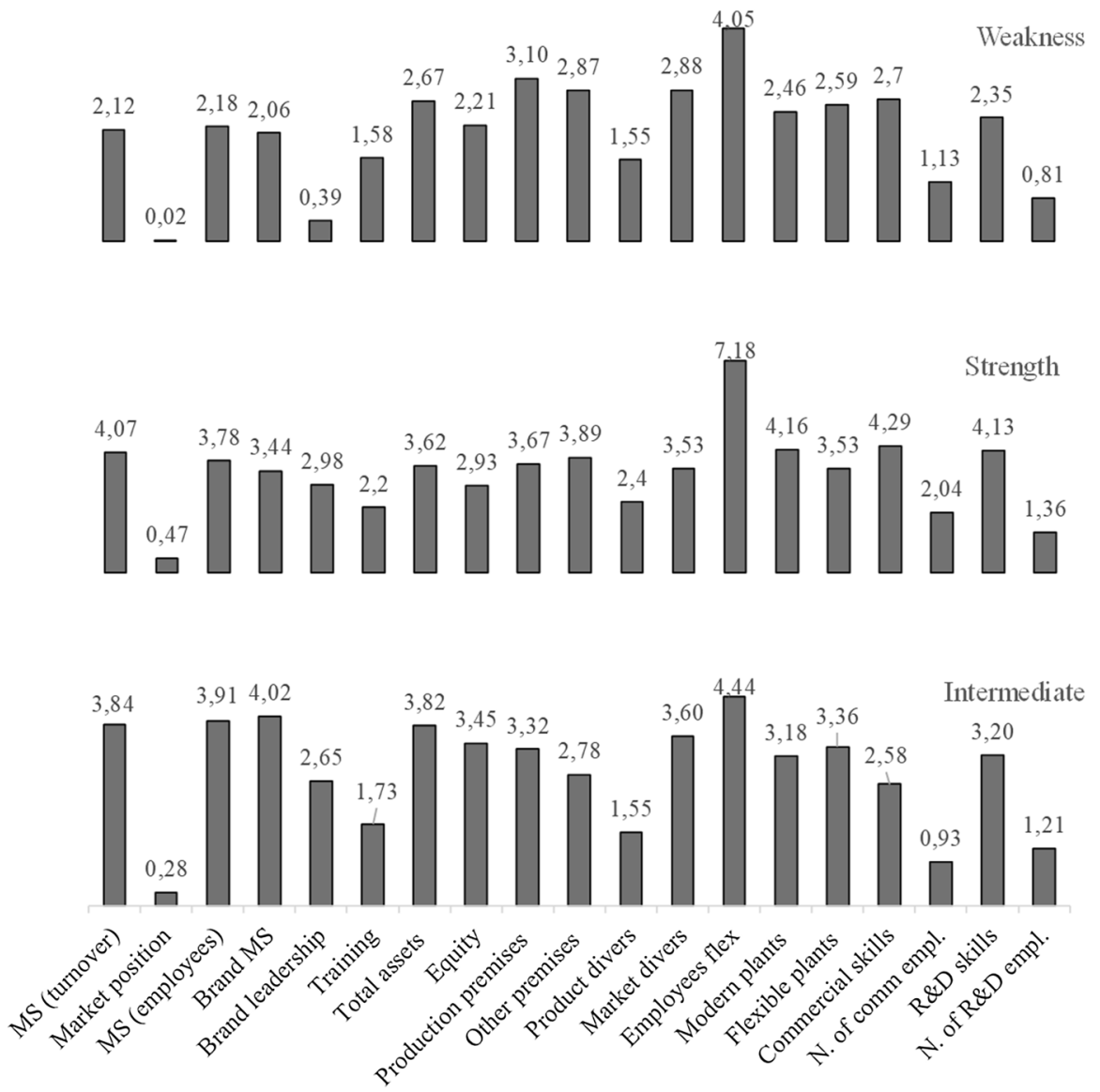

Fig. 5 Competitive position (relative to others) of the company Source: authors' elaboration using survey data

products (39.4\% in Europe in 2017) and expand in premium tiers as ready meals or healthier food ranges, increasing in such that way the average price per basket (IRI 2019).

Anova analysis on the solution is significant for all variables, as detailed in Table 6, endorsing that company's competitive position dimension is based on this solution to three clusters, with the nuance that the middle position is not so much for resources but by capacities smaller than the strong competitive position. We test by discriminatory analysis the adhesion of a first significant function $(\lambda 0.143)$ that explains $75.2 \%$ of the variance. In this function the variables with major weight are the ones that identify market power and also a variable of leadership, brand leader. It is also relevant to have financial resources (assets), and among skills, R\&D skills, up-to-date and flexible plants and to compete in several markets. Market power variables show correlation also with the second function, which has lower significance $(\lambda 0.529)$ and explains $24.8 \%$ of the variance. The variables with the largest 


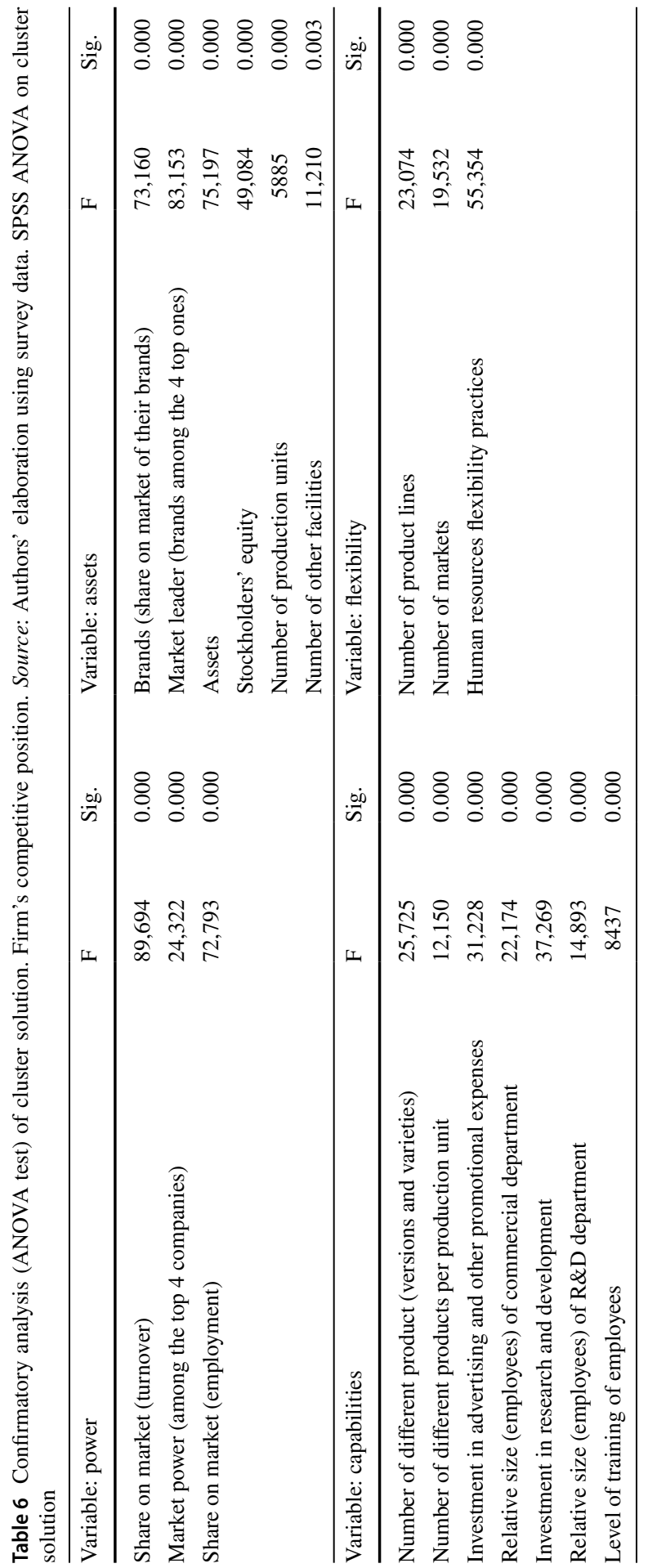


correlation with the second function are, in this order, flexible personnel, product diversification and flexible production plants, other facilities and trained personnel. The discriminatory analysis indicates that, in addition to the size (employees, assets) what distinguishes companies is the ability to translate in a customer-relevant offer the combination of resources and capabilities: market share is based on an attractive product by its brand offering (brand share) that is refined and improved (R\&D skills, upgraded plants). This combination provides a source of competitive advantage that is attractive to diverse customers (they compete across multiple products and across multiple geographic markets).

\subsection{Results: How Managers React. The Strategic Behavior of Companies When Facing Decline}

The items that describe the strategic actions, coming from previous literature, have been scored by executives using a 5-point Likert scale and have been totaled using the additive scale method in accordance with the competitive strategy they reflect. We have verified that they have an appropriate degree of reliability, consistency and convergence (confirmatory factorial analysis and Cronbach's $\alpha$ ). Competitive strategy of the business is the one with the highest average score (Acquaah and Yasai-Ardekani 2008), and as some of our respondent are diversified firms, that of the company is the one which corresponds to its main SIC (Leitner and Güldenberg 2010).

Table 7 shows competitive strategies classified according to SIC code (industrial segment) and company's size. Niche is dominant in an important business group, with regards to the number of companies, namely bakery products (205), populated in our sample by small, local and family-owned companies, which pursue the niche option to serve a local market. This result reflects the warning of a decrease in strategic alternatives. In Coffee and tea (2095) and dairy products (202) research has highlighted the existence of potentially attractive residual demand pockets. High-impact examples are the development of the coffee capsule market (Nestlé, Mondélez, Douwe Egberts) and local (La Fageda) and ecological (Danone) dairy new brands. Market power is predominant among juices (2037). This is in keeping with a sector highly polarized between major national brands and the retailer's private label (PL).

Regarding wines (2084), exit has an important presence. This result is surprising given the significant differentiation possibilities that the experts highlight for this sector, which would give rise to a larger presence of the niche option, and the opportunity of exports (Simon-Elorz et al. 2015). The classical region of origin wines (La Rioja, Ribera de Duero) come together with "novice" (young people and women) consumer demand of fresher and lighter wines (rosés and whites), a pattern observed in international markets (Zen et al. 2011). Harvest appears as the dominant alternative for oils and dairy products (along with niche in the latter case). This choice could prove to be optimal for companies that lack the investment capability necessary for differentiation or increased cost efficiency, as seen in low added value sectors.

Table 7 also details the competitive strategy according to firm size in terms of employment. The greater presence of costs and niche among large companies stands out, while among smaller ones cost efficiency is a minority alternative 


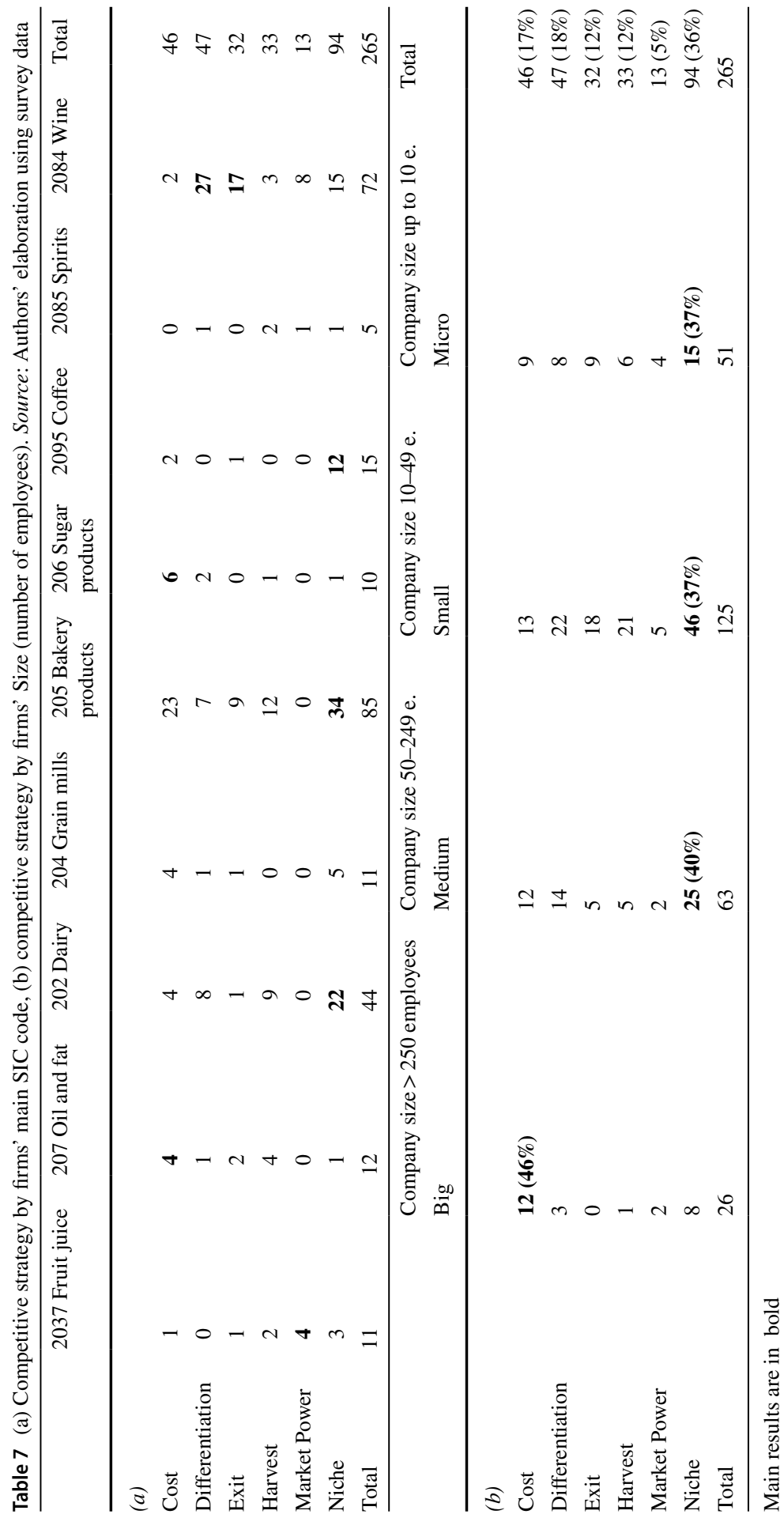


Table 8 Comparison of actual and prescribed strategic choice, Stay of Exit. Source: Authors' elaboration using survey data

\begin{tabular}{|c|c|c|c|c|c|}
\hline \multirow[t]{2}{*}{ Company's position } & \multicolumn{2}{|c|}{ Structure of decline } & \multicolumn{3}{|c|}{$\begin{array}{l}\text { Comparison of prescribed and followed } \\
\text { strategy }\end{array}$} \\
\hline & Unfavourable & Favourable & $\mathrm{N}$ & FP & NFP \\
\hline \multicolumn{6}{|l|}{ Weakness } \\
\hline \multicolumn{6}{|l|}{ Strategic choice } \\
\hline Exit & 20 & 17 & 37 & $78 / 121=64.46 \%$ & $43 / 121=35.54 \%$ \\
\hline Stay & 43 & 41 & 84 & & \\
\hline Total & 63 & 58 & 121 & & \\
\hline \multicolumn{6}{|l|}{ Strength } \\
\hline \multicolumn{6}{|l|}{ Strategic choice } \\
\hline Exit & 3 & 1 & 4 & $36 / 37=97.30 \%$ & $1 / 37=2.70 \%$ \\
\hline Stay & 16 & 17 & 33 & & \\
\hline Total & 19 & 18 & 37 & & \\
\hline \multicolumn{6}{|l|}{ Intermediate } \\
\hline \multicolumn{6}{|l|}{ Strategic choice } \\
\hline Exit & 5 & 6 & 11 & $29 / 71=40.84 \%$ & $42 / 71=59.16 \%$ \\
\hline Stay & 36 & 24 & 60 & & \\
\hline Total & 41 & 30 & 71 & & \\
\hline FP & $44 / 123=35.67 \%$ & $99 / 106=93.40 \%$ & & $143 / 229=62.45 \%$ & $86 / 229=37.55 \%$ \\
\hline NFP & $79 / 123=64.23 \%$ & $7 / 106=6.60 \%$ & & & \\
\hline
\end{tabular}

Main results are in bold

FP: follower of Prescribed strategic choice

NFP: non follower of Prescribed strategic choice

compared to niche and harvest. It is worth noting that, for SMEs companies, pure competitive strategies of differentiation and cost, seen at any life cycle stage, are of lesser relative importance compared to alternatives more associated with the decline stage, such as harvest and market power. Market power is exercised by large companies through cost superiority, while medium-sized companies become specialists in producing PL for retail customers or other F\&B marketers.

With the competitive strategy we know the strategic choice, Stay or Exit. a binary variable (Stay $=1$, Exit $=0$ ), reflecting the final aim of the strategy alternative. Table 8 summarizes that Stay is the preferred option (177), regardless of the competitive position. Only those in a strong or intermediate (in this case, only for a favorable environment) can stay: 67 of the total sample; the rest, 162, should exit or harvest). It is the companies in an intermediate competitive position which, to a greater degree, choose to stay in an unfavorable environment. In the case of companies in a weak competitive position, the positions are more even. When comparing the strategic choice prescribed by the model with the one actually implemented, and classifying companies according to whether they follow the prescribed strategic choice, followers of prescribed (FP) or not (NFP). we find 
Table 9 Descriptives of result variables. Source: Authors' elaboration with ORBIS-Bureau van Dijk archival measures of survey firms

\begin{tabular}{|c|c|c|c|c|c|c|}
\hline & \multicolumn{2}{|c|}{ Change on turnover } & \multicolumn{2}{|c|}{ Added value ( $\%$ on sales) } & \multicolumn{2}{|c|}{ Return on assets } \\
\hline & Mean & SD & Mean & SD & Mean & SD \\
\hline \multicolumn{7}{|l|}{ Strategic choice } \\
\hline Stay & 0.102 & 0.397 & -0.043 & 0.906 & 0.124 & 0.648 \\
\hline Exit & -0.338 & 1.073 & $0.147 *$ & 1.056 & $0.467 *$ & 0.688 \\
\hline \multicolumn{7}{|l|}{ Competitive Position } \\
\hline Weak & -0.128 & 0.808 & 0.155 & 0.964 & -0.221 & 0.833 \\
\hline Strong & 0.072 & 0.211 & -0.247 & 0.878 & 0.269 & 0.878 \\
\hline Intermediate & 0.181 & 0.359 & -0.135 & 0.909 & 0.137 & 1.103 \\
\hline \multicolumn{7}{|l|}{ Size } \\
\hline Micro & -0.064 & 0.548 & -0.478 & 0.995 & -1.181 & 3.587 \\
\hline Small & -0.194 & 0.850 & 0.173 & 0.969 & 0.130 & 3.053 \\
\hline Medium & 0.192 & 0.369 & -0.003 & 0.955 & 0.073 & 3.891 \\
\hline Big & 0.507 & 0.143 & -0.329 & 0.591 & 0.469 & 6.250 \\
\hline \multicolumn{7}{|l|}{ Sector } \\
\hline 207 Fats and oils & $-0.969 *(1)$ & 3.217 & $-1.217 *(1)$ & 0.309 & -0.257 & 0.333 \\
\hline 202 Dairy & 0.069 & 0.884 & -0.772 & 0.578 & 0.220 & 0.896 \\
\hline 204 Grain mills & $-0.402^{*}$ & 1.752 & -0.159 & 1.170 & 1.340 & 2.443 \\
\hline 2037 Fruit juices & 0.125 & 0.989 & 0.002 & 1.102 & 0.021 & 0.273 \\
\hline 2084 Wines & -0.045 & 0.702 & $0.167 *$ & 1.166 & -0.158 & 0.615 \\
\hline 205 Bakery products & 0.145 & 1.024 & $0.458^{*}$ & 0.739 & -0.048 & 0.947 \\
\hline 2061 Sugar & -0.519 & 0.771 & -0.479 & 0.664 & -0.900 & 1.899 \\
\hline 2095 Coffee and tea & 0.413 & 1.034 & -0.158 & 0.588 & 0.038 & 0.802 \\
\hline 2085 Spirits & -0.402 & 0.912 & 0.064 & 1.619 & 0.021 & 1.016 \\
\hline
\end{tabular}

*Difference of means is significant at the 0.05 level

(1) Abnormal result due to group consolidation

79 NFP that choose to stay and 7 that choose to exit, going against the prescription of the model, due to their competitive position or environment classification.

In the model of economic decline, economic results will be better for firms that adopt the recommended decision; in the case of performance, the outcome will be worse if the recommended decision is to exit (Porter 1980; Harrigan 1980). Table 9 summarizes the descriptives and highlights the significant results. Firms that decide to exit, immediately of after milking, obtain better value added and better ROA (return on assets) that firms that choose to Stay. However, control variable sector show significant differences in performance (change on income in the period 2007-2011) and economic results (added value and return on assets ratio). The size of the sample does not allow further detail so confirmation of the validity of the prescriptions of the model around prescribed strategies, and results, with regards to our research, is incomplete. 


\section{Discussion}

The study of dynamics of Spanish F\&B industry through the ILC model reveals that, in spite of an overall picture of stability, consumption of Spanish households declined in the period of the study however the total performance of the industry was better than the one of the total economy (Araújo-Vila et al. 2020). The exam of change trajectories (McGahan 2004) shows an overall pattern of intermediating change, where competitors, customers and suppliers force companies to act against their own profitability. In this overall picture, there are commodity products as sugar, oil and dairy that face a progressive change where decreasing demographics and dietary habits challenge the ability to keep growth. Other products as wine or coffee, however, show sights of progressive change, where innovation and diversification of products and market scope can increase the prospects of growth. Therefore, the study methodology applied to its different businesses allows us to confirm the validity and relevance of the ILC model as a tool to help practitioners to understand what the industry situation is and plan the next moves. The detailed examination of the various product groups and classes shows that the movement between stages can take the form of long-tail, the effect described by Klepper (1996), followed by a stage of maturity in decline or petrified demand (Harrigan 1988). The pattern of transition from maturity in decline to the decline stage is the result of progressive changes, which are hard to foresee, or exceptional negative changes or jolts, maybe as consequence of events (McGahan 2004). As a result, when observing the life cycle of an industry, the transition between maturity and decline must be reviewed, as the traditional phases do not always respond to business evolution (Fig. 6).

In this context of intermediate or progressive growth, domestic petrified demand, there are companies that react to the final decline of the product by implementing innovations in processes and uses (Henderson 1995), leading to a turnaround in their competitive position (Stopford and Baden-Fuller 1994) or a rebirth of the

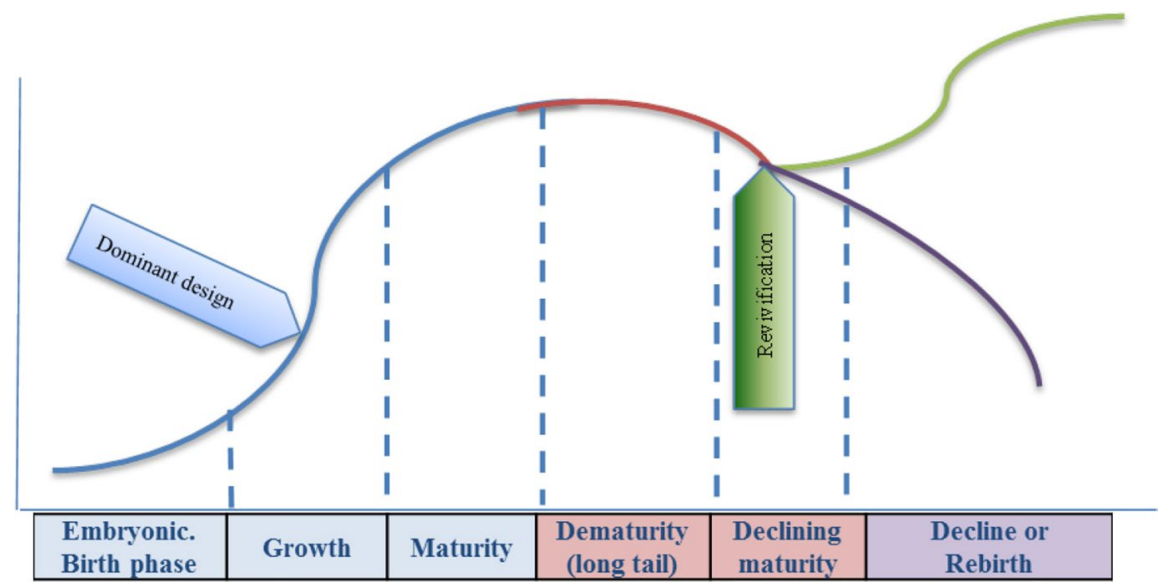

Fig. 6 Industry life cycle traditional phases revision from maturity to decline Source: Fujimoto 2014; Harrigan 1980; Henderson 1995; Klepper 1996; McGahan 2004 
industry (Christensen and Raynor 2003) and its limits (Cusumano et al. 2015). Markets evolve differently depending on the players operating in them. As reflected in the analysis of firms' competitive position, market share is based on an attractive product by its brand offering (brand share) that is refined and improved (R\&D skills, upgraded plants). As the destiny of the company is largely a result of its own actions and this effect is even more noticeable in times of adversity (Bamiatzi et al. 2016), industry evolution will reflect that there are companies that wish to stay due to their strategy choice, others try to exit, allocating the key assets of their business to new products and markets (McGahan 2004). In this research the main difference among the recommended strategy and the firms' behavior, is on Exit: 79 companies declared strategies to Stay, while the recommended one is the opposite. This behavior is consistent with the warning of Baden-Fuller (1989) on the reluctance of directors and owners, to exit the business as they lose their income source. Even more, family firms are reluctant to close the family legacy (Harrigan 1980).

However, strategic reorientation of the firm to be able to Stay, recovering the growth path, entails having the dynamic capabilities of flexibility and adaptation and the resources required for this (Teece 2007). That said, this global approach does not reflect the reality of the Spanish F\&B, populated by SMEs, with limited capabilities to take on new challenges (Covin and Slevin 1989), largely mature and with difficulties for industrial reorientation, as it has to deal with the origin of the product and the institutional context (regional systems of innovation do not focus in low R\&D industries, Autio 1998).As an example, for wineries that belongs to a designation of origin is not easy to leap from a variety of grape to another, matching consumers' needs (Fernández-Olmos et al. 2009). Their future fate is influenced by the attitude of managers if there is risk aversion, leading to conservative behavior, which discourages an innovative attitude and investment in dynamic capabilities that could change the rules of the game (Martin and Eisenhardt 2004).

Among the efforts to find new sources of demand, it is unsurprising that good prospects derived from an expansion of the market through exporting stand out (Simon-Elorz et al. 2015). Again, the export route for small, not very competitive companies is limited to operations of low added value, since the attractiveness of the offering is in their lower prices.

\section{Conclusion}

This study objective is the revision of the adequacy of ILC as a theoretical framework and model when analyzing and comparing industries and firm's actual behavior and results. In order to do that, we set a complete and detailed revision of theory's prescriptions reviews with the empirical validation of the model of competitive behavior proposed by the ILC literature. The results point out that ILC framework, considering the last refinement, continues to be a good model to incorporate into environmental dynamism into analysis. The study contributes with a methodology and revision of sources that can be helpful for further research that also takes ILC model as the grounding theory. However, the comparison among the model prescribed strategic choice and the enacted one points a major concern in the current 
context of new normality and saturated markets. With an average increase on GDP in the Eurozone of 1.9\% (Eurostat 2019) and the forecasted impact of COVID-19 in world economy, the exit or harvesting prescriptions formulated in the ' 80 are not easily applicable. Thus, there is a need for more studies that refine and refresh prescriptions on mature and declining industries, taking into consideration the positive learnings on the relation of internationalization and knowledge and fostering the support of national and regional systems of innovation.

However, the study is not without limitations, because of its pioneering orientation, and also because of the information sources, as is using a sample of companies. The choice of consumption may be challenged as the predictor of decline, especially in export businesses; a potential combination of production and consumption will be useful. Also, as the strategic conduct is different than the prescribed option, we can't study the link with performance as results are not significant enough. In spite of the limitations, we foresee future research needs in the light of our results. First one is to tackle progressive change and the complex process of creating new products, as innovation requires companies to have the necessary human and intellectual capital. The study of knowledge networks and open innovation, to impulse knowledge and cooperation, is an application of research to which we humbly hope to contribute. The second area of study has to do with the reduction of uncertainty. From the academic viewpoint, companies, organizations and governmental agencies must take a proactive approach to supporting the recovery and updating of the information tools. As a stroking example, the Strategic framework for the F\&B industry (MAPA 2018) describes it with 2012 figures. Many SMEs lack the access to industrial prospects from private research companies. Hence, the effort of dissemination of knowledge of industrial organizations as FIAB or academic research is also worth to consider.

\section{References}

Acquaah, M., \& Yasai-Ardekani, M. (2008). Does the implementation of a combination competitive strategy yield incremental performance benefits? A new perspective from a transition economy in SubSaharan Africa. Journal of Business Research, 61(4), 346-354.

Araújo-Vila, N., Fraiz-Vila, J. A., \& de Araújo, A. F. (2020). Spanish economic-financial crisis: Social and academic interest. Journal of Business Cycle. https://doi.org/10.1007/s41549-020-00045-z.

Argyres, N., Bigelow, L., \& Nickerson, J. A. (2015). Dominant designs, innovation shocks, and the follower's dilemma. Strategic Management Journal, 36(2), 216-234.

Audretsch, D. B., \& Feldman, M. P. (1996). Innovative clusters and the industry life cycle. Review of Industrial Organization, 11(2), 253-273.

Audretsch, D., Sanders, M., \& Zhang, L. (2017). International product life cycles, trade and development stages. The Journal of Technology Transfer. https://doi.org/10.1007/s10961-017-9588-6.

Autio, E. (1998). Evaluation of RTD in regional systems of innovation. European Planning Studies, 6(2), 131-140.

Baden-Fuller, C. W. F. (1989). Exit from declining industries and the case of steel castings. Economic Journal, 99(398), 949-961.

Bamiatzi, V., Bozos, K., Cavusgil, S. T., \& Hult, G. T. M. (2016). Revisiting the firm, industry, and country effects on profitability under recessionary and expansion periods: A multilevel analysis. Strategic Management Journal, 37(7), 1448-1471.

Barney, J. (1991). Firm resources and sustained competitive advantage. Journal of Management, 17(1), 99-120.

Bloom, N. (2014). Fluctuations in uncertainty. Journal of Economic Perspectives, 28(2), 153-175. 
Burpitt, W., \& Fowler, S. (2007). Entrepreneurial strategies in a declining industry. Journal of Small Business Strategy, 18(1), 69-84.

Calori, R., \& Ardisson, J. M. (1988). Differentiation strategies in 'stalemate industries'. Strategic Management Journal, 9(3), 255-269.

Campelo, A., Bittencourt, V. S., \& Malgarini, M. (2020). Consumers confidence and households' consumption in Brazil: Evidence from the FGV Survey. Journal of Business Cycle Review, 16, 19-34. https://doi.org/10.1007/s41549-020-00042-2.

Caves, R. E., \& Porter, M. E. (1977). From entry barriers to mobility barriers: Conjectural decisions and contrived deterrence to new competition. The Quarterly Journal of Economics, 91, 241-261.

Christensen, C. M., \& Raynor, M. (2003). The innovator's solution: Creating and sustaining successful growth. Boston, MA: Harvard Business School Press.

Covin, J. G., \& Slevin, D. P. (1989). Strategic management of small firms in hostile and benign environments. Strategic Management Journal, 10(1), 75-87.

Cuervo-Cazurra, A., Narula, R. and Un, C. A. (2015). Internationalization motives: Sell more, buy better, upgrade and escape (January 26, 2015). http://dx.doi.org/10.2139/ssrn.2939444

Cusumano, M. A., Kahl, S. J., \& Suarez, F. F. (2015). Services, industry evolution, and the competitive strategies of product firms. Strategic Management Journal, 36(4), 559-575.

Dess, G. G., \& Beard, D. W. (1984). Dimensions of organizational task environments. Administrative Science Quarterly, 29(1), 52-73.

Dess, G. G., \& Davis, P. S. (1984). Porter (1980) generic strategies as determinants of strategic group membership and organizational performance. Academy of Management Journal, 27(3), 467-488.

Dieli, O. J. (2020). Industry lifecycle of Nigeria's Telecom sector: Possible trajectories after deregulation. Journal of Applied Business and Economics, 22(2).

Elfenbein, D. W., \& Knott, A. M. (2015). Time to exit: Rational, behavioral, and organizational delays. Strategic Management Journal, 36(7), 957-975.

Esteve-Perez, S., Pieri, F., \& Rodriguez, D. (2018). Age and productivity as determinants of firm survival over the industry life cycle. Industry and Innovation, 25(2), 167-198.

European Union (EU) (v.d.). Eurostat, European Union statistical board: Structural business statistics, SBS. Retrieved from: https://ec.europa.eu/eurostat/web/structural-business-statistics/overview; National accounts and GDP. Real GDP growth, 2008-2018. https://ec.europa.eu/eurostat/statistics -explained/index.php?title=National_accounts_and_GDP

Fernandes, N. (2020). Economic effects of coronavirus outbreak (COVID-19) on the world economy. https://papers.ssrn.com/sol3/papers.cfm?abstract_id=3557504

Fernández-Olmos, M., Rosell-Martínez, J., \& Espitia-Escuer, M. A. (2009). Vertical integration in the wine industry: A transaction costs analysis on the Rioja DOCa. Agribusiness, 25(2), 231-250.

Fischer, C., \& Schornberg, S. (2007). Assessing the competitiveness situation of EU food and drink manufacturing industries: An index-based approach. Agribusiness, 23(4), 473-495.

Fujimoto, T. (2014). The long tail of the auto industry life cycle. Journal of Product Innovation Management, 31(1), 8-16.

Grant, R. M. (1991). The resource based theory of competitive advantage: A resource-based view. California Management Review, 115.

Hall, W. K. (1980). Survival strategies in a hostile environment. Harvard Business Review, 58, 75-85.

Hammermesh, R. G., \& Silk, S. B. (1979). How to compete in stagnant industries. Harvard Business Review, 57, 161-168.

Harrigan, K. R. (1980). Strategies for declining businesses. Boston, MA: Lexington Books.

Harrigan, K. R. (1985). An application of clustering for strategic group analysis. Strategic Management Journal, 6(1), 55-73.

Harrigan, K. R. (1988). Managing maturing business: Restructuring declining industries and revitalizing troubled operations. Boston, MA: LC Books.

Harrigan, K. R., \& Porter, M. E. (1983). End-game strategies for declining industries. Harvard Business Review, 61, 111-120.

Henderson, R. (1995). Of life-cycles real and imaginary-The unexpectedly long old-age of optical lithography. Research Policy, 24(4), 631-643.

IMF, International Monetary Fund. (2017). Informe país: España (Country reports: Spain). Retrieved from https://www.imf.org/ /media/Files/Publications/CR/2017/cr1724.pdf

INE, Spanish National Institute on statistics (v.d.).: Estadistica estructural de empresas, EEE. (Statistics of firms' structure). Retrieved from https://www.ine.es/jaxiT3/Datos.htm?t=28379\#!tabs-tabla ; Directorio central de empresas, DIRCE (Centralized census of companies). Retrieved from https 
://www.ine.es/dyngs/INEbase/es/operacion.htm?c=Estadistica_Candcid=1254736160707andmenu $=$ resultadosandidp $=1254735576550$

IRI, Information resources incorporated. (2019). Regional value share for private label grows to highest levels at 39.4\%. https://www.iriworldwide.com/es-ES/Insights/news/Private-label-outperform s-FMCG-brands-in-Europ-(1).

Jackson, T. (2019). The post-growth challenge: secular stagnation, inequality and the limits to growth. Ecological Economics, 156, 236-246.

Karniochina, E. V., Carson, S. J., Short, J. C., \& Ketchen, D. J, Jr. (2013). Extending the firm vs. industry debate: Does industry life cycle stage matter? Strategic Management Journal, 34(8), 1010-1018.

Klepper, S. (1996). Entry, exit, growth, and innovation over the product life cycle. American Economic Review, 86(3), 562-583.

Klepper, S. (1997). Industry life cycles. Industrial and corporate change, 6(1), 145-182.

Leitner, K.-H., \& Güldenberg, S. (2010). Generic strategies and firm performance in SMEs: A longitudinal study of Austrian SMEs. Small Business Economics, 35(2), 169-189.

Levitt, Th. (1960). Marketing myopia. Harvard Business Review, 38(4), 45-56.

Levitt, T. (1980). Marketing success through differentiation-of anything (pp. 83-91). Graduate School of Business Administration, Harvard University.

Levitt, Th. (1983). The globalization of markets. Harvard Business Review, 61(3), 92-102.

Madhavaram, S., \& Hunt, S. D. (2008). The service-dominant logic and a hierarchy of operant resources: developing masterful operant resources and implications for marketing strategy. Journal of the Academy of Marketing Science, 36(1), 67-82.

MAPA, Spanish Ministry of Agriculture, Fishery and Food (v.d.): Panel de consumo alimentario (2000 a 2018). Households food consumption panel Retrieved from https://www.mapa.gob.es/es/alimentaci on/temas/consumo-y-comercializacion-y-distribucion-alimentaria/panel-de-consumo-alimentario/; Anuario estadístico (2000 to 2018). Yearly statistics (2000 to 2018). Retrieved from https://www. mapa.gob.es/es/estadistica/temas/publicaciones/anuario-de-estadistica/default.aspx; Informe marco estratégico (2018) https://www.mapa.gob.es/es/alimentacion/temas/industria-agroalimentaria/marco -estrategico/; Informe anual indicadores (2019), https://www.mapa.gob.es/es/ministerio/servicios/ analisis-y-prospectiva/informe_anual_indicadores2018_tcm30-513683.pdf.

Martin, J. A., \& Eisenhardt, K. M. (2004). Coping with decline in dynamic markets: Corporate entrepreneurship and the recombinative organizational form. Business Strategy over the Industry Life Cycle, 21, 357-382.

McGahan, A. M. (2004). How industries change. Harvard Business Review, 82, 86-94.

McGahan, A. M., \& Silverman, B. S. (2001). How does innovative activity change as industries mature? International Journal of Industrial Organization, 19(7), 1141-1160.

Miles, G., Snow, C. C., \& Sharfman, M. P. (1993). Industry variety and performance. Strategic Management Journal, 14(3), 163-177.

Narver, J. C., \& Slater, S. F. (1990). The effect of a market orientation on business profitability. Journal of Marketing, 54(4), 20-35.

O'Sullivan, M. (2020). Industrial life cycle: relevance of national markets in the development of new industries for energy technologies-The case of wind energy. Journal of Evolutionary Economics. https://doi.org/10.1007/s00191-020-00677-5.

Orbis, Spanish data base of financial balances, Bureau van Dijk.

Oster, S. M. (1999). Modern competitive analysis. OUP Catalogue: Oxford University Press.

Parker, B., \& Helms, M. (1992). Generic strategies and firm performance in a declining industry. Management International Studies, 32, 23-40.

Porter, M. E. (1980). Competitive strategy. Techniques for analyzing industries and competitors (1998 with a new introduction). New York: Free Press.

Porter, M. E. (1991). Towards a dynamic theory of strategy. Strategic Management Journal, 12, $95-117$.

Reportlinker (v.d): Food And Beverages Global Market Report 2018. "Amid the COVID-19 crisis" business reports on bakery, dairy, seafood, spirits and other food and Beverages, retrieved from https ://www.prnewswire.com/news-releases; Spanish Food Industry, 2020-2024. Global Food Industry, 2020-2024. European Food Industry. Retrieved from https://www.reportlinker.com/ci02024/Food. html.

Simon-Elorz, K., Castillo-Valero, J. S., \& Garcia-Cortijo, M. C. (2015). Economic performance and the Crisis: Strategies adopted by the wineries of Castilla-La Mancha (Spain). Agribusiness, 31(1), $107-131$. 
Spanish Food and Drink industry federation, FIAB (v.d.). Informe Económico (Yearly economic report). Retrieved from http://fiab.es/categoria-producto/informes-economicos/

Stopford, J. M., \& Baden-Fuller, C. W. (1994). Creating corporate entrepreneurship. Strategic Management Journal, 15(7), 521-536.

Teece, D. J. (2007). Explicating dynamic capabilities: The nature and microfoundations of (sustainable) enterprise performance. Strategic Management Journal, 28(13), 1319-1350.

Thiètart, R. A., \& Vivas, R. (1983). Success strategies for declining activities. International Studies of Management \& Organization, 13(4), 77-92.

Tong, T. T., Yu, T. E., Jensen, K., Ugarte, D. D., \& Cho, S. H. (2016). Impact of public infrastructure on output of US food manufacturing industries: A heterogeneous dynamic panel approach. Agribusiness, 32(4), 439-453.

Vernon, R. (1966). International investment and international trade in the product cycle. The Quarterly Journal of Economics, 80(2), 190-207.

Zen, A. C., Fensterseifer, J. E., \& Prévot, F. (2011). Internationalization of clustered companies and the influence of resources: A case study on wine clusters in Brazil and France. Latin American Business Review, 12(2), 123-141.

Publisher's Note Springer Nature remains neutral with regard to jurisdictional claims in published maps and institutional affiliations. 